\title{
Breytt vígstaða í stríðinu við reykingar
}

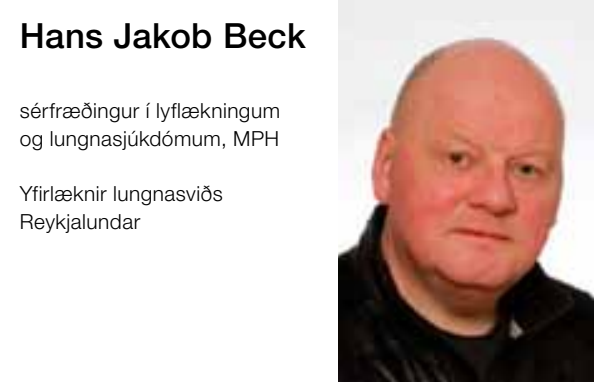

hjabeck@gmail.com

Sígarettureykingar breiddust út um heimsbyggðina í heimsstyrjöldinni síðari. Pá var lítið vitað um skaðsemi peirra, en tæknivædd framleiðsla og markaðssetning samfara herflutningunum tryggðu pessum banvæna fylginaut vestrænnar menningar stöðu sem kostað hefur margfaldar mannfórnir styrjaldarinnar.

Nú er rafrettan komin fram á sjónarsviðið. Ný tækni, ný markaðssetning; sama nikótínið. Nýr bölvaldur eða traustur bandamaður í baráttunni? Hvoru tveggja er haldið fram, svo hverju á að trúa? Allir eru pó sammála um að rannsóknir skorti enn.

Orðið rafretta hefur verið notað yfir tækið sem á ensku heitir „electronic cigarette“ eða „e-cigarette“. Pjált orð, en tengir notkunina augljóslega reykingum. Enskumælandi notendur reykja ekki rafrettur heldur nota sögnina "to vape" dregið af vapour. Heyrst hefur nýyrðið vepja, bæði yfir tækið og athöfnina. Á sama hátt mætti nota orðið eima eða nikótíneima.

Rafrettan er rétt rúmlega 10 ára gömul uppfinning og breiddist út um heiminn frá Kína. Petta er stautur í premur hlutum: rafhlöðuhylki, hitari og munnstykki með vökvalykju og skammtahólfi. Vökvinn er annaðhvort própýlen glýkól eða glýseról, með eða án nikótíns. Pað kviknar á hitaranum pegar sogið er í munnstykkið og skammtur af gufu berst ofan í notandann. Rafrettur eru bæði til einnota og margnota og hægt að blanda sjálfur bragðefnin í vökvann. Nikótínstyrkur vökvalykjunnar er mismunandi, en yfirleitt á bilinu 6-24 mg.

Rannsókn frá 2013 benti til að um helmingur fólks á enska málsvæðinu pekkti rafrettur, 8\% hefði prófað pær og 3\% væru notendur peirra. Í Bandaríkjunum jókst hundraðshluti rafrettunotenda úr 0,6\% árið 2009 í 6,7\% árið 2010. Notkunin breiðist sérstaklega mikið út meðal ungmenna, en markaðssetningin er öflug og fer ekki síst um netið og félagsmiðla. ${ }^{1}$

Viðbrögð yfirvalda og ýmissa læknasamtaka hafa einkennst af áhyggjum og óvissu. Stefnuyfirlýsing Bandarísku hjartalæknasamtakanna leggur meðal annars til stangt aðhald við aðgengi barna og unglinga að rafrettum, mælir með að pær verði settar undir lög um tóbak og leggur til að Matvæla- og lyfjastofnuninni, FDA, verði falið að hafa aukið eftirlit. Enn sem komið nær eftirlit stofnunarinnar með rafrettum aðeins til notkunar við reykingameðferð. ${ }^{2}$

Sameiginleg stefnuyfirlýsing alpjóðaráðs lungnalæknafélaga gengur lengra og leggur hreinlega til rafrettubann par til meira er vitað um heilsufarsleg áhrif, en að öðrum kosti ættu eftirlit og reglur að vera eins og með lyfjum og tóbaki.

Yfirvöld, bæði í Bandaríkjunum og Evrópu, glíma við að setja rafrettum lagaramma og má búast við meira aðhaldi og eftirliti pegar á pessu ári. Frá og með 2016 munu rafrettur til dæmis lúta sama eftirliti og lyf í Bretlandi. Á Íslandi falla efni sem innhalda nikótín undir lyfjalög frá 1994 og er innflutningur og dreifing rafretta og íhluta peirra með nikótíni bannaður.

Gagnrýnendur rafretta benda á óvissuna um áhrif peirra, par eð rannsóknir skorti. Framleiðslan sé mismunandi og óstöðluð. Vökvinn og eimurinn innihaldi skaðleg efni og nikótínið sjálft sé eitrað í of miklum styrk. Nikótínfíkn gæti breiðst út meðal ungmenna og aukið reykingar. Rafrettan gæti viðhaldið reykingum og deyft áhugahvöt til reykleysis.

Peir sem hlynntastir eru rafrettunni benda á að hún sé miklu skaðminni en reykingar, hún hjálpi fólki að hætta reykingum og geti í raun verið lykillinn að pví að útrýma reykingum með pví að verða ofaná í samkeppninni.

En hvað vitum við um rafrettuna? Reykingafólk hefur tekið peim vel og upplifir að pær hjálpi við að minnka reykingar eða hætta peim. Rannsóknir styðja petta og benda til að rafrettur megi nota til að draga úr skaðsemi nikótínneyslunnar og neyslan virðist ekki fara úr böndunum og aukast eins og óttast var. Reykingar virðast dragast saman par sem rafrettur ná útbreiðslu. Engar alvarlegar aukaverkanir hafa komið fram og pó rannsóknir sýni ertingu í öndunarfærum, dregur úr öndunarfæraeinkennum reykingamanna við rafrettunotkun vegna minni reykinga. Rafrettan virðist hins vegar ekki leysa sígarettuna af hólmi, aðeins $12-14 \%$ reykingamanna sem prófuðu hana urðu daglegir notendur. ${ }^{3}$ Útbreiðsla rafrettunnar meðal reyklausra, sérstaklega ungmenna, er áhyggjuefni og vísbendingar eru um að rafrettur gætu aukið reykingar í peim hópi. Eimur rafrettunnar inniheldur skaðvænleg efni, en í miklu minna mæli en sígarettureykur og umhverfisáhrif rafrettunnar felst aðeins í útöndunarlofti notandans, ekki reyk frá bruna eins og í tilfelli sígarettunnar.

Heimsstyrjöldinni er löngu lokið, en stríðið við sígaretturnar stendur enn. Rafretturnar eru komnar fram á völlinn og hafa breytt vígstöðunni. Nýir möguleikar eru í stöðunni fyrir sjúklinga okkar, en pað má hins vegar ekki missa stjórnina í pessu stríði. Mikilvægast er nú að fylgjast vel með öllum hreyfingum og vera tilbúinn til pess sem kannski er erfiðast: að skipta um skoðun.

\section{Heimildir}

1. Schraufnagel DE, Blasi F, Drummond MB, Lam DCL, Latif E, Rosen MJ, et al. Electronic cigarettes. A position statement of the forum of international respiratory societies. Am J Respir Crit Care Med 2014; 190: 611-6.

2. Bhatnager A, Whitsel L, Ribisl KM, Bullen C, Chaloupka F, Piano MR, et al. Electronic cigarettes: a policy statement from the American Heart Association. Circulation 2014; 130: 1418-36.

3. Hajek P, Etter JF, Benowitz N, Eissenberg T, McRobbie H. Electronic cigarettes: review of use, content, safety, effects on smokers and potential for harm and benefit. Addiction 2014; 109: 1801-10.

The war on smoking: Changing strategic position

Hans Jakob Beck pulmonary physician, MPH Medical Director dep. of Pulmonary Rehabilitation Reykjalundur Rehabilitation Centre 